\title{
Euro Area Sovereign Debt Crisis: What Economic Policy Consequences and Implications for the Franc Zone African Countries?
}

\author{
Isaac Tamba \\ Correspondence: Isaac TAMBA, Faculty of Economics and Management, University of Yaounde II, Cameroon. \\ And Research Center for Sustainable Development in Africa (RCSDA), P.O. Box 7536 Yaounde, Cameroon. Tel: \\ 237-70-751-050 or 237-22-204-832. E-mail: isatamba@yahoo.fr
}

\author{
Received: May 30, 2012 \\ Accepted: June 21, 2012 \\ Online Published: July 12, 2012 \\ doi:10.5539/ijef.v4n8p186 \\ URL: http://dx.doi.org/10.5539/ijef.v4n8p186
}

\begin{abstract}
The recent notation degradation of the sovereign debt of the Euro area countries was at the origin of some confusing rumours on the effects of the loss of "Triple-A rating" for these countries as well as for the Franc Zone African Countries (PAZF). The need to protect the European Financial Stability Fund (EFSF) together with the lack ofeconomic competitiveness of the PAZF caused by the structural overvaluation of the CFAFranc and the no optimality of the Franc Zone are some of the destabilizing factors of the CFAlikely to induce queries about the zone including that which concerns the revision of the currency parity. The financial forfeiture of the Euro countries in general, and in France in particular, provides the opportunity to reconsider the current monetary anchoring by envisaging several happier perspectives for the PAZF, beginning with the keeping of the status quo $o$ the building of the competitiveness of the African economies with the creation of a "CEMAC Franc" or a "WAEMU Franc" within the framework of a system of fixed exchange rates with margins of fluctuations. Irrespective of the policy adopted, the ultimate objective shall be to gradually move towards the "post- CFA" era which shall be followed by the creation of a unique African currency before 2020. This discussion goes well beyond the traditional analyses on the need to revise the 1972 and 1973 agreements between France and PAZF as it incorporates elements of the 2011 financial crisis in the debate.
\end{abstract}

Keywords: competitiveness, monetary crisis, devaluation, euro, EFSF, CFA Franc, Post- CFA, Euro area, franc zone

\section{Introduction}

Several conclusions can be drawn from the downgrading of the sovereign debt note of some Euro countries including France (note 1). Apart from the risk of recession, other risks can be identified such as the persistent degradation of the notes of States facingeconomic hardship, the adoption of a new European Treaty and the implosion of the Euro area, just to name a few. Any of these scenarios shall have an impact on the economies of the Franc Zone African Countries (PAZF), most especially with the status of the CFA Franc.

First of all, this deterioration is proof of the economic and financial difficulties that these countries are experiencing now, as it reveals the persistence of the imbalance of their public finances and the competitiveness lacunas of their respective economies and the financial effort of France in rescuing the eurowhich has helped countries facing economic challenges such as Italy, Spain and Greece.

Secondly, the major consequences of this downgrading go far beyond the increase of the country's risk and the mistrust of investors and markets. Slow growth perspectives, more expensive sovereign debt, concomitant increase of the credit charges and heavy consequences on employment rate and wealth creation are to be expected.The chain of the reduction of the financial note of Euro countries has direct consequences on the PAZF economies (note 2)

Assuming that the CFA Franc is a datum and that everything remains equal in the temporal horizon of the implementation of the development plans of the PAZF based on the Poverty Reduction Strategies (DSRP of the second generation), the question is to know whether it is reasonable to consider the current monetary Franc anchoring of the zone as a threat or as an opportunity in terms of growth, jobs and social well-being.

In order to answer this question, it will be germane to endeavour to prove that the sovereign debt crisis raging in the Euro area is a threat for the PAZF economies. 
Then, considering the direct and potential consequences (note 3) of the sovereign debt crisis in the Euro areaon the PAZF which are being fed by a model of anachronistic development (note 4), associated with the permanent overvaluation of the F.CFA which slows down exports and overbids imports, compromising considerably the competitiveness of these economies, it will be necessary to find out whether the next move is towards a status quo, the decline of the CFA Francleading to the explosion of the zone, a new devaluation of the CFA Franc, or again, whether the next move is towards the creation of sub-regional currencies (note 5).

Answering this second question calls for the estimationand anticipation of the effects of the active solidarity between France and Euro countries (thus in favor of the EFSF) to the detriment of the Franc zone, on one hand and for the examination of the consequences of an implosion of the Euro area due to the dysfunctions of this fund, whichmay arise from its incapacity to reach the objectives set at the time of its creation in May 2010 on the other hand.

The paper aims at assessing the impact of the European financial crisis on the PAZF generally and on the stability of the CFA Franc in particular, the likelihood of its transmission and the opportunity which it gives to these countries to renegotiate the current monetary framebuilt on the CFA Franc.

\section{The Sovereign Debt Crisis of the Euro Area: A Threat for the PAZF Economies}

The most immediate consequence of the Euro area debt crisis is the trust crisis that befalls on the national debts of the member States of the zone with together with its impact on mechanisms set up by the European Union to mitigate that crisis and the European Financial Stability Fund (EFSF). In effect, the AAA note of this fund depends on that of the countrieswhich support it, and in this case, Germany and France. It allowed the affected countries (Portugal, Greece, Spain) to borrow on the same conditions as Germany (2\%) or France (3\%). Since January 13th, 2012, Aid plans in these countries have become more expensive. It may thus have a reverse effect on the sustainability of anti-crisis measures griped in September 2011. In so far as it continues to weaken the European currency position, and consequently that of the CFA Franc, a domino effect is to be feaded. Banks had announced the events of January 13th, 2012 when they suspended negotiations with Greece on the modalities of the restructuring of its national debt which meant that they could come back on their promise to reduce Greece's debt by half!

As the capacity of the PAZF to meet their development goals depends on the status of the currency among other things, several questions arise: the first is to know whether the need to protect the EFSF might lead the European Central Bank (ECB) and Germany to impose new institutional arrangements to France such as the revision of the agreements governing the Franc zone and, in particular, the unlimited guarantee granted to the CFAFranc. According to the terms of the monetary cooperation agreement of November 23rd, 1972 between the Bank of the States of Central Africa and France on one hand, and those of the monetary cooperation agreement of December 04th, 1973 between France and the member States of theWest Africa Economic and Monetary Union (WAEMU) on the other hand, the French State guarantees the convertibility of the currency emitted by the BEAC by granting it an unlimited right to draw on an"Operation Account (note 6)"opened in the French Treasury. In exchange of this, he BEAC and the BCEAO have to deposit a fraction of their clear outer exchange reserves on the"Operation Account".

The European Relief Fund (EFSF) aims at collecting funds in order to finance the loans of the Euro member States facing financial difficulties which cannot borrow on capital marketsat affordable rates. It raises funds more easily when rating agencies give the maximal note whichis AAA. The reduction of the note of several Euro countries led to the EFSF'striple A being downgradedto AA +. A brief analysis of the activities of the fund shows that its balance sheet was very thin in February 2012, and that it did not meet the expected goals (note 7). This makes it possible to foresee that some risks related to the dysfunctions of this fund whose operation margins are already reduced due to the difficulties that it meets in carrying out its activities without the maximal note.

In the case where there is no significant change, the EFSFwill not collect as much funds as needed to pay off the debt of Euro countries and simultaneously implement Greece's aid plan. Such a situation which will certainly occur can further weaken this zone which would then implode with a domino effect on the CFA Franc.

In taking into account the pace at which the French budget deficit is increasing (note 8), the question arises as to whether the current parity of the CFA Franc will resist. In other words, under the pressure of the markets and of other Euro countries, will France be able to resist to a devaluation of the CFA Franc in order to strengthen the balance of its exchanges with the PAZF economies, considering the fact that in spite of its significant reduction, the level of exchanges between the PAZF and European Union countries is still high (note 9). 
Of the low level of trade between the Franc zone countries and Euro countries' exchanges with emerging countries co-exists with the increasing importance in the trade between emerging countries and Franc zone countries. For example, from 2002 to2008, the Chinese part in the trade of the PAZF has increased to $4 \%$ of the total of the trades of the zone to $14,5 \%$, with an average part of about $10 \%$ of the exchanges. The positions of India, Brazil, Russia and South Africa are more moderated (note 10). This is to say that the current difficulties of the Euro area present risks because the PAZF economies are exposed both to the consequencesthe slowness of European growth and the possible slowdown of Chinese, Indian and Brazilian growth.

In addition, the strong appreciation of the eurois accompanied with another risk driven by the Chinese presence: the underestimation of the Yuan which reduce the competitiveness of trade between the PAZF and China.

The first preliminary conclusion is that the potential dysfunctions of the EFSF and the abyssal budget deficit of France associated to the slow down of the world growth that can contribute to a revision of the current status of the CFA Franc towards the Euro.

Had the reasoning been based on the basic economics of the PAZF, factors which are likely to justify a refitting of the current monetary device can seem derisory in comparison to the situation that has prevailed in the beginning of the 1990s when the CFA Franc was devaluated, even if the Franc zone is less competitive with regard to other African countries (Myburgh and Fall, on 2011). Indeed, in spite of the overvaluation of the CFA Franc, the rate of exports of raw products is constantly increasing in the CEMAC and WAEMU zone, and this was not the case in 1994. Likewise, the growth rates are positive, with an average of 6,5\% in the CEMAC zone in the last 10 years, and 3,5\% in the WAEMU zone (figure 2). The latter is still influenced by the low growth potential of Ivory Coast (note 11).

A good number of scholarly works (TchundjangPouemi, 1980; Monga and Tchatchouang, 1996, etc.) show that the monetary relations between France and the PAZF benefits more to the former than to the latter, through the"Operation Account"opened in the Bank of France (note 12), and special economic relations that it has with all these countries via the CFA Franc, for other scholars on the other hand (Guillaumont and Guillaumont, 1988 and 1992; Lelart, 2003; Vinay, 1988). The monetary cooperation between France and PAZF provides many advantages to the latter (note 13). In addition, they assert that the mechanism of the Franc zone providesprotection (note 14) and useful railings against the food, energy and financial crisis of 2008 and 2009 (note 15).

In spite of these advantages and in the light of the functioning of the Franc zone, its optimal character has not been demonstrated (note 16). Indeed, notwithstanding the type of approach taken, whether it is traditional(note 17) or new (note 18), most empirical works on the optimal character of the Franc Zone conclude that the revenue to be gained from the adoption of a common currency such as the CFA Franc, or a regime of fixed exchange rates cannot compensate the costs of renunciation of the exchange rate as an adjustment instrument within the zone so long as there is more mobility within the zones than out of it for the workforce and for the financial flows or direct investment (Bayoumi, on 1994).

Likewise, the McKinnon theory, which makes arbitrating fixed exchange rates - floating exchange rates depend on the volume of trade in the same way as Kenen's theory on the diversification of State's economies (1969) seems not to apply to the PAZF (note 19). The analysis of the degrees to which these countries carry out transactions (ratio of intra-community exports/GDP in percentage) as well as the ascendancy of the monocultures of export is enough to achieve demonstration (note 20).

Furthermore, Prao (2010) demonstrated that apart from the failure of the CFA Franc to achieve the PAZF development, the principles of the Franc zone canamply explain their economic regression.

For example, ananalysis of the economic trajectories of PAZF and non PAZF between 2003 and 2009 shows that the economic performances of the PAZF were below those of non-PAZF over the same period. The estimatesare $6,5 \%$ the average increase of the GDP of other Africa sub-Saharan countries for an average of 3\% and approximately $4,2 \%$ for the PAZF of the WAEMU and CEMAC groupings. The difference in the growth of the GDP during the period under review are sometimes very high, as in 2006 and 2007, when the growth of PAZF was $6,5 \%$ and $6,9 \%$ and $2,9 \%$ and $3,2 \%$ in $2006,3,2 \%$ and $4,7 \%$ in 2007 , respectively for WAEMU and CEMAC (Note 21).

However, and during the same period, the results in terms of inflation control were much better in the WAEMU and CEMAC, even if in 2008, the level of consumption prices was exceptionally high: $7,4 \%$ and $6,9 \%$ in WAEMU and CEMAC respectively as comparedwith an average of about 2,5\% for the WAEMU zone and 2,7\% 
for the CEMAC zone between 2003 and 2007 (figure 1), while the level of Africa sub-Saharan countries was 8,1\% (IMF, Perspectives of the world economy, April, 2010).

As far as thecontribution of the Franc zone to the regional integration is concerned, the debate and the position revolve around three main standpoints. First of all, those who propound the idea that the Franc zone balance sheet is positive, (Guillaumont and Guillaumont, 1988; Hugon , 1999; Gerardin, 1994, 1999; etc.) and that it is not possible to envisage the Franc zone without France (Yondo, 1997); then those who underline the pernicious effects of the current monetary anchoring policy (Ondo Ossa, 2003; Monga and Tchatchouang, 1996; Tchundjang Pouemi, 1980; etc.) and those who recommend a monetary structuring that promotes the creation and strengthening of national (Nzemen, 1997) or regional currencies in the process of integration (Bekolo-Ebe, 1997).Some economists (Dramani, 2010) assert that the integration in Franc zone is"institutional"and that the outcomes are different in WAEMU or in CEMAC. The macroeconomic instability prevailing within the PAZF led to an important flight of capital estimated by Ndikumana and Boyce (2007) at about 50 billion dollars between 1970 and 2004. These authors, quoted by Ndiaye (2011), assert that for every dollar lent to the PAZF, 60 hundreds leave these countries under capital flight.

The cover rate of the CFA currency should be at $20 \%$. However, the cover rate is now at $112 \%$. There is a margin of important operation, whichcould have been used to finance the structuring projects for PAZF economic development.

As a matter of fact, the foreseeable economic and institutional transfers in the Euro area with possible consequences on the status of the CFA Franc strengthen these traditional analyses on whether or not the existence of the Franc zone is relevant. Hence, questions remain as to the appropriate monetary strategy for the PAZF.

\section{The Sovereign Debt Crisis of the Euro Area: An Opportunity to Reorganize the Current Monetary Framework of the CFA Franc}

As in 1994, the sovereign debt crisis of the Euro area has nurturedexpectations of devaluation from an economic variable proportion of agents leading tocapital flight (Myburgh and Fall, on 2011). In spite of the reassuring comments of the respective monetary authorities of both monetary unions, the fear of devaluationis still pregnant and it may lead to anuncontrollable spiral. It is worthy to Note that monetary crises cannot be entirely explained by solvency problems or by slow growth. The risk to which the PAZF are exposed today may well be explained by other vulnerabilities that are mostly institutionaland which may amplify or result in a monetary crisis. $\mu$ It therefore becomes urgent thatthe PAZF should react (Note 22) and work towards ending the current monetary cooperation between the PAZF and France (Gankou and Bondoma, 1998).

What is currently taking place in the Euro area shows that a system of fixed exchange rates - such as that of the Franc zone - is vulnerable. The reason is that the monetary anchoring can be questioned on the basis of factors that do not depend on satellite countries. For example, doubts as to the capacity of experimental countries to finance an outside deficit (first generation crisis) or the anxieties generated by the activity trends and unemployment rate (second generation crisis).

Therefore, economic policy recommendations aim at ensuring the realization of the PAZF development goals which are:

- In the short term, to examine the scenario developed in the second cycle of programming of the DSRP (Note 23), and reasonably move towards a continental currency; while improving efforts to manage the public finances system, according to budgetary issues and in consideration of the financial fragility of the governance systemwhile accelerating the implementation of the PAZF competitiveness strategy to limit the inconveniences of a strong Euro as reference currency. The potential advantages linked to the access of the PAZF to the large European market will not be as effective as the evanescent effects of the devaluation of January, 1994.

- to undertake a monetary structuringwithin CEMAC and WAEMU by setting up the"CEMAC Franc"and the "WAEMU Franc"within the framework of a system of stable exchange rates with fluctuation margins. Choosing this type of regime would likely beprompted by considerations relating to the revamping of regional integration, on one hand, and to the existence of a dominant State on both sides (Cameroon and Ivory Coast, respectively), that are used to stabilize such monetary strategies which should be able to impose rules on other members and support the related costs.

This floating administered regime, the preliminary floating in a continental currency possibly connected with other currencies refers to the concept of -target-zone or "-objective-zone", as defined by Williamson (1986) as a margin of fluctuation in the exchange rates on both sides of a rate of balance fixed according to the real data. 
Sotherefore, due to variations, the central bank can let its currency depreciate in the short term, without running neither the risk of a flight of capital, nor the loss of exchange reserves, especially if there are anticipations of the future appreciation of the currency with regard to the central course. The -target-zone thus reduces the volatility of the exchange rates which is due for the main part to the behavior of the speculators who, in such a system, is very different from that which will obtain in the presence of perfectly flexible exchange rates (Krugman, on 1995).

For Williamson, the system of -target-zone is a viable alternative to both polar systems (fixed exchange rates and floating exchange rates). Indeed, this regime of administered fluctuations:

- Contributes to postpone the relative desires of a sovereign monetary strategy in a context where additional efforts must be provided to set up the budgetary discipline $\mathrm{n}$ the long run as is still the case with CEMAC and WAEMU groupings.

- Moves closer to the inconveniences/advantages of the fixed and floating regimes;

- Reconciles the various inflation rates through the automatic adjustment of the nominal target.

- Facilitates the adjustment of the balances of payments with the modification of the real central rate;

- Ensures the degree of dependence of the monetary policy due to the wider margins;

- Absorbs the speculative shocks by the existence the aforementioned margins.

Nevertheless, the institution of slippery parities in this new context has to follow some modalities: the determination of the exchange rate of fundamental balance (towards an experimental or reference currency (the euro) followed by the post-determination of the width of fluctuations margins.

One of the uncontested gains of this new regime of exchange is the role whichit could play to accelerate the process of regional integration in Africa generally. It is useful to keep in mind that for a country like Cameroon to reflect on the relationship between Euro andFCFA in the concept of regional integration and international recognition of the country (Vision 2035, p. 75) shows that the will of domestic public authorities to opt for a unique continental common currency by 2020, through the implementation of three African financial institutions. In relation to this, the General Secretary of the New Partnership for the Development of Africa (NEPAD) reaffirmed the will of Africa to have a single currency, taking into account the fact that this process goes through the sub-regional organizations, which have to work at gathering quickly around common currencies as a prelude to an African single currency.

As a matter of fact, these currencies, which would be part of the regime of slippery parities, would strengthen economic integration in regionsby providing solutions to the problems related to the risk of exchange and of shortage of reserves due to the creation of payment unions. 50 years after their accession to independence, the time has come for the PAZF to attain the monetary sovereignty by steadily getting out of a currency which eventually be subjected to devaluation bearing into mind that it is not a panacea.

Creatinga unique African currency on the basis of regional experiences is one of the objectives of the African Union (AU) created in 2001. To achieve this, the AU would use monetary unions of the five existing regional economic communities as intermediates towards the establishment of a central African bank and a common currency. While simulating the succession of a single currency in Africa, Masson and Pattillo (2004) demonstrated that CEMAC countries suffer from a loss in general well-beingif such a currency is created due to the accompanying rigorous management of their budgetary policy. Therefore, in the prospect a unique African currency, they propose that the Franc zone besubjected to selective extension as the practices of the neighboring countries converge on the members who already have a common monetary policy and currency.

Some of the new issues to be addressed by this new monetary strategy including the question as to whether the new CFA Franc should be disconnected to the euro with the significant suppression of the "Operation Account", and the consequential loss of the French guarantee of convertibility of the CFA Franc. The solutions will depend on the capacity of member states to undertake, jointly and equally, the necessary measures for the convergence of economic, financial and social policies in the new monetary territory. After all and by paraphrasing Hugon (1999), the choice that the PAZF is that of the universal and potentially benefits of multilateralism, and the cooperative multilateralism learned from historic and colonial links leading to a "reprimairisation" of economies. The current crisis callsfor more boldnessfrom the PAZF, a proof that, contrary to the Malian and Malagasy experiences (1973), monetary freedom is not"freedom to go bankrupt". 
The second preliminary conclusion is that the current Euro financial crisis an opportunity for the PAZF to reach a monetary autonomy through a process that will end in the establishment of the "CEMAC Franc" and the "WAEMU Franc" to be used in CEMAC and WAEMU respectively.

\section{Conclusion}

It is unnecessary to demonstrate the importance of finance in the process of development, several studies having shown bidirectional links between finances and economic growth (Murinde, 2010; Ahmed, 2010; Akinlo and Egbetunde, 2010). The PAZF development project may only come true only if the status of the currency is prevails in Europe gives a unique opportunity for the political authorities of these countries to take measures likely to favor their monetary independence within the framework of the UA which is to reach a create a unique African currency by 2021. The foregoing arguments developed have revealed the difficulties the PAZF could meet, if the current statu quo persisted; well beyond the loud voices raised for pro-devaluation in the last quarter 2011, the PAZF should stay stillwhen faced with the potential dysfunctions of the EFSF.

\section{References}

Ahmed, A. D. (2010). Financial liberalization, financial development and growth linkages in Sub-Saharan African countries: An empirical investigations. Studies in Economics and Finance, 27(4), 314-339. http://dx.doi.org/10.1108/10867371011085156

Akinlo, A-E., \& Egbetunde, T. (2010). Financial development and economic growth: The experience of ten Sub-Saharan African countries revisited. The Review of Finance and Banking, 2(1), 17-28.

Banque de France. (2009). Les échanges commerciaux de la zone Franc avec les pays émergents. Rapport annuel de la zone Franc, Paris.

Banque de France. (2009). Rapport annuel de la zone Franc, 2009, Paris.

BCEAO. (2005). Stabilité financière e gestion macroéconomique dans l'UMOA, $3^{\mathrm{e}}$ Colloques BCEAO Universités - Centres de recherche, Dakar.

BEAC. (2007). Echanges commerciaux des pays de la CEMAC au cours des dix dernières années, in Banque de France, Rapport de la zone Franc 2006, Paris.

Bekolo-Ebe, B. (1997). Monnaies régionales, monnaies nationales: Quelle structure monétaire pour le développement de l'Afrique? Zone Franc face à la monnaie unique européenne: Quel avenir? Fondation Friedrich-Ebert/ISMP, Yaoundé, pp.65-87.

Codesria. (1996). Symposium international sur l'avenir de la zone franc avec l'avènement de l'Euro, Dakar, Novembre.

Davanne O. (2000). Origine, déroulement et prévention des crises monétaires, collection des rapports du conseil d'analyse économique, La Documentation française.

Devarajan, S., \& De Melo, J. (1992). Membership in the CFA zone: Odyssey an journey or Trojan horse. Economic reform in sub-Saharan Africa, pp. 25-31.

Dramani Latif, A-G. (2010). Convergence and economic integration in Africa: the case of the Franc Zone countries, AERC, RP 200, Nairobi.

Engone Mve S. (2004). La politique monétaire et l'intégration sous-régionale. Laboratoire d'Economie Appliquée, Gabon.

FMI. (2010). Perspectives de l'économie mondiale, mise à jour juillet 2010, Washington, D.C.

Fondation Friedrich Ebert. (1997). La zone Franc face à la monnaie unique européenne: Quel avenir? Institut Supérieur de Management Public.

Fondation Friedrich Ebert. (1993). L'impact d'une dévaluation du FCFA: le cas du Cameroun, CRETES.

Friedman, C. (1991). Exchange rate policy, in "Monetary policy instruments for developing countries, (edited by CaprioJr, G and Honohan, P.), A World Bank Symposium, The World Bank, Washington, pp. 125-130.

Gankou, J-M., \& Bondoma Yokono, D. (1998). Gestion du taux de change et politique d'ajustement dans les pays africains membres de la zone Franc. Economica, Paris.

Gerardin, H. (1994). La zone Franc, Tome 2: La dynamique de l'intégration monétaire et ses contraintes,.l'Harmattan, Paris. 
Gullaumont, P., \& Guillaumont, S. (eds). (1988). Stratégies de développement comparées zone Franc et hors zone Franc. Economica, Paris.

Gullaumont, Pet Guillaumont, S. (1992). Exchange rate policies and the social consequences of adjustment in Africa. Economic reform in sub-Saharan Africa, pp. 12-24.

Herlin, P. (2012). La France, la faillite? Après la perte du AAA, $2^{\text {ème }}$ édition. Groupe Eyrolles, Paris.

Hugon, P. (1999). La zone Franc à l'heure de l'euro. Karthala, Paris.

Hugon, P. (nd). Les avatars de la zone France face à l'Euro, pp. 239-261.

Krugman, P. (1995). Globalization and the inequality of nations. The Quarterly Journal of Economics, 110(4), 857-80, November, MIT Press.

Lelart, M. (1996). Un exemple d'intégration institutionnelle: l'évolution de la zone Franc, Orléans, Doc de recherche, Institut orléanais de finance.

Masson, P., \& Pattillo, C. (2004). Une monnaie unique pour l'Afriqu. Finance et Développement, FMI, pp. 9-15.

Minepat. (2009). Vision Horizon 2035, Yaoundé, 85 p.

Monga, C., \& Tchatchouang, J-C. (1996). Sortir du piège monétaire. Economica, Paris.

Murinde, V. (2010). Financial development and economic growth: Global and African evidence. Journal of African Economics, 21, i10-i56. http://dx.doi.org/10.1093/jae/ejr042

Myburgh, L., \& Fall, C. (2011). Assessment on potential CFA Franc devaluation. CitiFx and Strategy, Johannesburg, December, $10 \mathrm{p}$.

Ndiaye Saloum, A. (2001). Capital flight and its determinants in the Franc zone, AERC, RP 215, Nairobi.

Ndikumana, L., \& Boyce, J-K. (2007). New estimates of capital flight from sub-Saharan African countries. Linkages with external borrowing and policy options, paper prepared for Seminar on capital flight in Pretoria, November 2007.

Nzemen, M. (1997). Monnaie régionale, monnaie nationale: Quel moyen pour la promotion du développement de l'Afrique? Le processus du Bon sens monétaire, Zone Franc face à la monnaie unique européenne: Quel avenir? Fondation Friedrich-Ebert / ISMP, Yaoundé, pp.53-64.

Ondo Ossa A. (2000). Zone monétaire et crise de change: le cas de la zone franc africaine. Laboratoire d'Economie Appliquée, Gabon.

Plane, P., \& Tanimoune, N-A. (2004). Performances et convergence des politiques économiques : la zone Franc en Afrique de l'Ouest, Document de travail de la série Etudes et documents, CERDI, 28 p.

Prao, S. (2010). Les pays africains de la zone Franc sont toujours colonisés, 50 ans après leurs indépendances, Webographie.

Tamba, I. (1994). Mesures d'accompagnement à la dévaluation du F.CFA: le cas du Cameroun, Revue Techniques Financières et Développement, No 35, Epargne Sans Frontières, pp. 36-41.

Tamba, I. (2005). L'Etat et le développement dans les pays de la CEMAC: une perspective historique, in Revue Etudes et StatistiquesBEAC, no 2997, juillet 2005, pp. 1-29.

Tchundjang Pouemi, J. (1981). Monnaie, servitude et liberté : la répression monétaire de l'Afrique, Les Editions J.A/Editions Conseil, 285 p.

Theret B. (éd). (2008). La monnaie dévoilée par ses crises, Collections, Civilisations et sociétés, vol I et II, Paris.

Touna Mama, Bekoko Ebe, B., \& Hakim B-H. (sd). (2003). Intégration économique en Afrique centrale, L'Harmattan.

Vinay, B. (1981). Zone Franc et coopération monétaire, La Documentation française, Paris.

Williamson, S-D. (1986). Costly monitoring, financial intermediation and equilibrium credit rationing. Journal of Monetary Economics, 18, 159-179. http://dx.doi.org/10.1016/0304-3932(86)90074-7

Yondo, M. (1997). La zone Franc sans la France? Zone Franc face à la monnaie unique européenne: Quel avenir, Fondation Friedrich-Ebert / ISMP, Yaoundé, pp.17-23.

\section{Notes}

Note 1. January 13th, 2012, Standard and Poor degraded the Note of France's sovereign debt and at the same time lowered that of eight other countries of the Euro area, among which Italy, Spain and Austria. Germany, 
Finland, Luxembourg kept their "triple A", as proof of strength of their resilience when faced with the ongoing financial crisis, and especially the confidence placed by markets in the policies formulated and implemented by these countries.

Note 2. Apart from other economic effects, the potential reduction in the flows of money of the Diaspora in Europe generally because of the economic slowdown, among other consequences.

Note 3. In particular, the reduction in the orders of European companies to their PAZF counterparts, the concomitant reduction of exports to Europe, cuts it with the volume of the financial aid because of their budgetary difficulties, etc.

Note 4. This is due to the fact that the PAZF takes part in the international market with raw material.

Note 5. By holding that the best option for Africa would be to move gradually towards a continental currency by 2020 , it will appear that the choice of the"improved status quo"current or sub-regional currencies seems to be more noticeable than that of national currencies when compared with the indiscipline which still prevails in the management of the PAZF public finances.

Note 6. The"operation account"is a tool that makes it possible to implement of the cooperation principles. Operation accounts are current accounts opened with the French Treasury in the name of each of the three emission establishments: the BCEAO, the BEAC and the central Bank of the Comoros. They are remunerated and offered the possibility of unlimited overdrafts. The economist Tchundjang Pouemi (1980) used this mechanism to prove the unbalanced character of the relations between France and PAZF. He considered among other things that the assets of the PAZF deposited in this account being placed in American vouchers of treasure on financial markets paid by superior rates from 4 to 5 points to those practiced in France. Nowadays, they are paid by the French Treasury at the profitable rate of the marginal ease of loan of the ECB. For the BCEAO and the BEAC, the amount of the deposits exceeding the share which must be formally maintained at the expense of operations leading to reduced remuneration, namely the rate of the main operations of refinancing of the ECB.

Note 7. Indeed by that time, only eight bond subscriptions were emitted, for some 25 billions euro volume at an average rate close to $3 \%$. At the same time, loans towards Ireland and Portugal, at the average rate of 5,3\%were made. A margin of more than $2,2 \%$ is so required from countries which need financing, in exchange for the guarantee offered by the fund.

Note 8. According to the INSEE (National Institute for Statistics and Economic Studies), the national debt of France reached 1700 billion euro, more exactly 1692.7 billions on June 30th, 2011. On March 31st, 2011, it amounted to 1646,3 billion euro, is a progress of 46,4 billions in three months, in other words 515 million euro a day. France incurs debts at the rate of 500 million euro a day (Herlin, 2012)!

Note 9 . Indeed, it was reduced from $45 \%$ in 1995 to approximately $30 \%$ in 2008 , in front of the United States $(17 \%)$ and China (14\%).

Note 10. Their respective average is $1,8 \%, 1,1 \%, 1,0 \%$ and $0,4 \%$ of the total of the exchanges of the PAZF.

Note 11. The IMF plans for 2012, an 8,5\% growth rate, what will contribute to re-revitalize the regional growth.

Note 12. The free convertibility of the currency of each of the sub-zone is ensured by the operations account on which central banks have unlimited right to draw in the case of an exhaustion of their currency reserves. In exchange of this right to draw, central banks have to put down at the expense of operations a part of their clear outer assets (exchange reserves) and must meet some requirements. For the BCEAO, the part of the outer assets that must be deposited at the operation account is fixed to $50 \%$ since the reform of September 2005. For the BEAC, the quota was reduced from 65 to $60 \%$ on July 1st, 2007 then further lowered to $50 \%$ on July 1 st, 2009 . For the Comoros, it is $65 \%$.

Note 13. In this case, history shows that inflation has been better managed in the PAZF than non-PAZF, because of their monetary and financial stability, the strengthening of the credibility of the CFA. F, the abolition of the foreign exchange risk intra PAZF, the convergence of economies by means of the fixed exchange rate and the implementation of the solidarity principle through compensation between member countries ...

Note 14. In effect, the anchoring of the CFA Franc in the Euro limited the volatility of the courses of raw materials, the regulations of exchange limited the outside exposure of the financial system, and the monetary stability reduces inflation pressures.

Note 15. They were not sufficient to check, or to say the least, stabilize the escalation of the deficit of the PAZF trade balance. For example, Cameroon's trade balance records historic deficits for six years that went as high as approximately $6 \%$ of the GDP in 2010. In the context of strong structural rigidity and (lengths) deadlines of 
reaction of an economic policy to improve the competitiveness of the economy, the «rule of affectation"of Mundell consisting in affecting the monetary policy - via the instrument that is the exchange rate - in the only task of the external rebalancing is inoperative in Franc zone.

Note 16. Ondo Ossa (2000) for example, admits the optimality of the Franc zone by its end and proposed a new CFA Franc over a long period.

Note 17. Introduced by Mundell (1961), McKinnon (1963) and Kenen (1969), the theory of the optimal Monetary area concentrated on the costs of a monetary union and on the definition of the optimal goals of the monetary areas.

Note 18. They relate to the criteria of Ingram and Scitovsky as well as those of Bourguinat and Kindleberger, on one hand and on the more recent work of Bayoumi, Ghosh and Wolf, Melitz, Devarajan, Minford, Ricci, on the other hand.

Note 19. The modern criteria establish the necessary conditions of optimality, as any monetary area, which fulfills these conditions, is not necessarily optimal. Neither the nearness of the national preferences giving rise to a consensus between the member countries of the zone on the essential determiners of their economies (Bourguinat), nor the intensity of the exchanges and the existence of identical preferences (Kindleberger) are enough to protect the monetary area from exogenous shocks.

Note 20. The ratio trades intra zonal / total foreign trade is of little significance and the ratio exports intra zones / GDP is very low. According to the BEAC, the intracommunity commercial transactions considered partially relatively little important global flows: they represent about $3 \%$ of the total value of $t$ exchanges (that is FCFA 119 billions a year). The WAEMU's participation does not exceed $1 \%$ of trade with of CEMAC Countries (BEAC, 2006).

Note 21. IMF: perspectives of the world economy in April 2010, updated in July 2010

Note 22. Devarajan and Melo (1992) already showed the cost of the waiting-game (in terms of loss of competitiveness and points of growth) observed in the PAZF in the 1980s because due to the delay in achieving the process of currency adjustment.

Note 23. They incorporate the relation Euro-CFA.F within the framework of regional integration.

Note 24. Namely, the African central Bank to be installed in Nigeria, the African Bank of investment in Libya and the African monetary Fund in Cameroon.

Note 25. In 2003, the Association of the governors of the African central banks announced that it would try to set up a single currency and a common central bank by 2021.

Note 26. These are the Arabic Monetary Union, the Common market of East and southern Africa (COMESA), the Economic Community of the States of Central Africa (CEEAC), the Economic Community of the States of western Africa (ECOWAS), the southern Africa Development Community (SADC).

Note 27. 10.000 billion CFA. F (that is near million euros) are deemed to be the amount of assets that both African central banks provided to the Bank of France, who serve finally only to guarantee the fixed parity of the CFA Franc.

Note 28. After the retreat of Mali and Madagascar of the Franc Zone, respectively in 1962 and 1973, these two countries experienced heavy difficulties, which forced to reinstate the zone in 1984 !

Note 29. The 1994CFA Franc devaluation in and the coming into being of the Economic and Monetary Union in Europe in 1999 were historic opportunities for the PAZF to reflect on currency status in their respective economies. 
Appendix

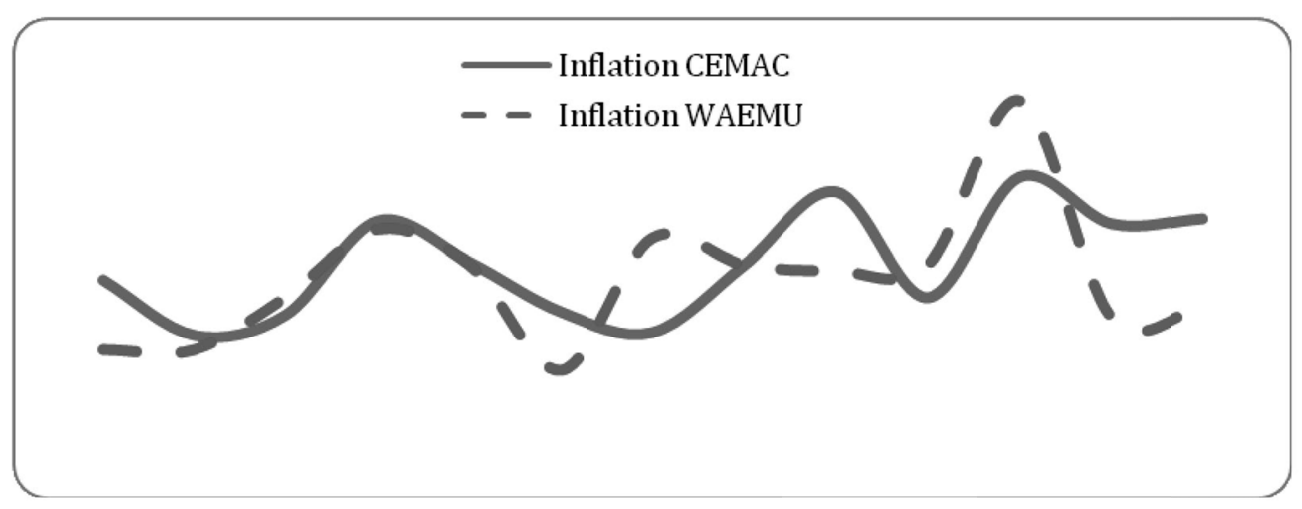

Figure 1. Inflation in the CEMAC et UEMOA groupings

Sources: IMF (2011), Report on the common policies of the CEMAC member countries, Washington, D.C., 71p. BCEAO (2011), Annual Report 2010.

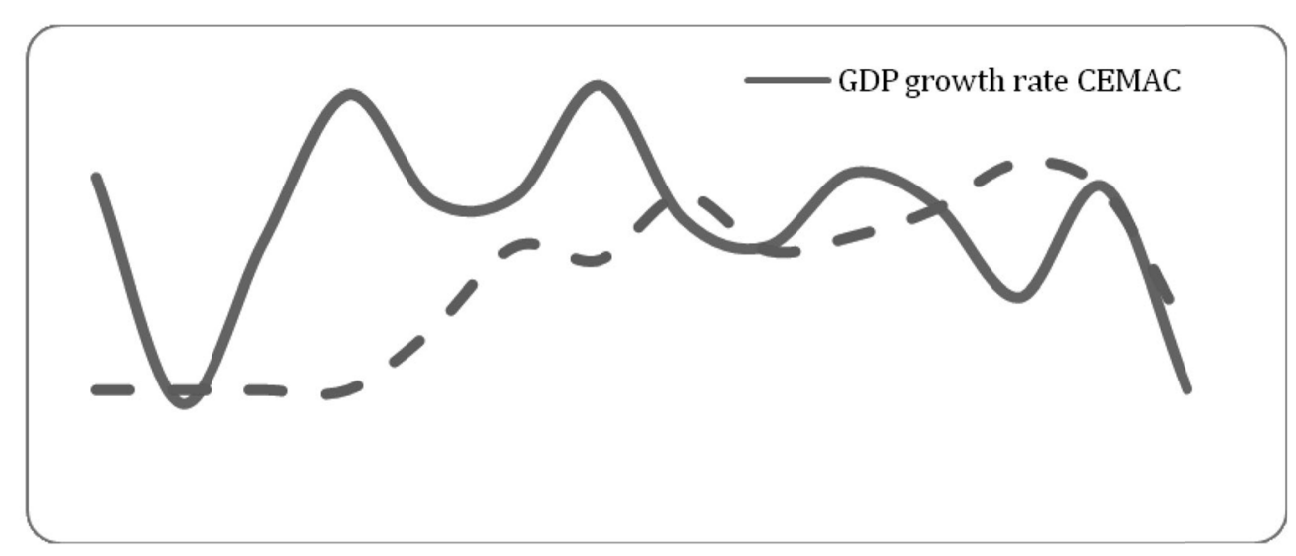

Figure 2. Growth rate in the CEMAC and WAEMU groupings

Source: Ibidem

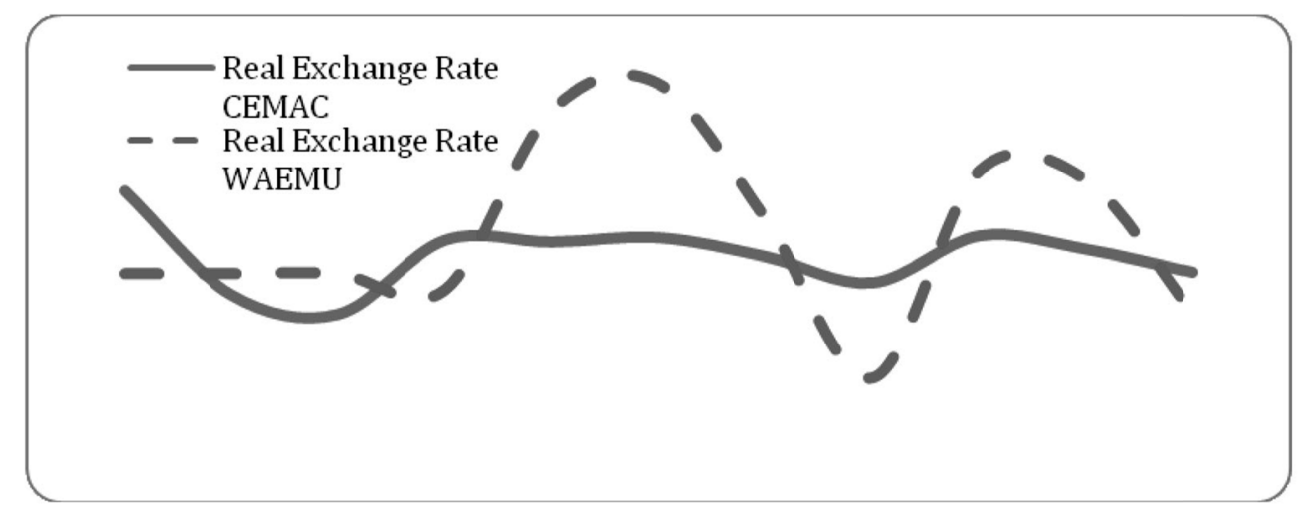

Figure 3. Real exchange in CEMAC and WAEMU groupings

Source: Ibid 